\title{
Temporal arteritis and trigeminal neuralgia overlap syndrome: A case report
}

\author{
Temporal arterit ve trigeminal nevralji overlap sendromu: Bir olgu sunumu
}

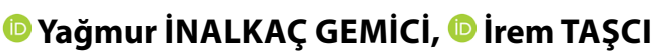

\begin{abstract}
Summary
Temporal arteritis and trigeminal neuralgia are rare causes of a headache, and the combination is rarer still. The present patient was diagnosed with temporal arteritis at the age of 60 years and presented with trigeminal neuralgia after the sedimentation rate had returned to normal under treatment. The underlying cause of neuralgia in cases of temporal arteritis varies. This report is an examination of the rare association of the 2 conditions and the available literature.

Keywords: Inflammation; overlap syndrome; temporal arteritis; trigeminal neuralgia.

\section{Özet}

Temporal arterit ve trigeminal nevralji başağrısının az görülen nedenlerinden olup birliktelikleri çok daha nadirdir. Sunmuş olduğumuz olgu 60 yaşında önce temporal arterit tanısı alıp tedavi altında sedimentasyon normale döndükten sonra trigeminal nevralji ile prezente olmuştur. Temporal arteritte nevralji görülmesinin altında yatan neden ise değişken olabilir. Biz bu vakada literatür eşliğinde nadir görülen bu birlikteliği ele almayı amaçladık.

Anahtar sözcükler: Inflamasyon; overlap sendromu; temporal arterit; trigeminal nevralji.
\end{abstract}

\section{Introduction}

Temporal arteritis (TA) is an inflammatory vasculitis affecting large and medium arteries. TA is mostly seen in people aged over 50 years and can involve the central and peripheral nervous systems. ${ }^{[1]}$ One of the peripheral involvements is a short-lasting neuralgiform headache characterized by unilateral electric shock-like pain. ${ }^{[2]}$ In this report, we reviewed a patient who presented with TA followed by with trigeminal neuralgia (TN) in light of literature.

\section{Case Report}

A 60-year-old female patient was admitted to our outpatient clinic with a two-month history of a throbbing pain in her left temple which occurred every day and continued throughout the day and blurry vision in the left eye. The patient also had sensitivity in the temple area along with nausea and fever. The patient was prediagnosed with TA based on the patient history and an erythrocyte sedimentation rate (ESR) of $132 \mathrm{~mm} / \mathrm{h}$. Accordingly, the patient was hospitalized and initiated on pulse steroid therapy (1,000 $\mathrm{mg} /$ day methylprednisolone) without biopsy due to the risk of vision loss and since the patient met 4 out of the 5 diagnostic criteria for TA. The laboratory parameters assessed during the differential diagnosis were as follows: C-reactive protein (CRP), $17.8 \mathrm{mg} / \mathrm{dl}$; ESR: $132 \mathrm{~mm} / \mathrm{h}$, haemoglobin: 10.3\% and platelet count: $547,000 \mu / \mathrm{L}$. Vasculitis panel was negative. The patient showed a dramatic response to the treatment and also had reduced fever, improved anaemia and thrombocytosis, and a reduction trend in ESR. Depending on these findings, the patient was referred to the Rheumatology clinic. The patient was started on immunosuppressant therapy with leflunomide but was later switched to monthly treatment with anti-IL-6 monoclonal antibody therapy with the addition of oral steroids (methylprednisolone). The oral steroid dose was gradually reduced to $8 \mathrm{mg} /$

Department of Neurology, Malatya Training and Research Hospital, Malatya, Turkey

Submitted: 13.12.2018 Accepted after revision: 28.05.2019 Available online date: 26.06.2019

Correspondence: Dr. İrem Taşcı. Malatya Eğitim ve Araştırma Hastanesi, Nöroloji Kliniği, Malatya, Turkey.

Phone: +90 - 536 - 9550534 e-mail: tasciiirem@gmail.com

(c) 2019 Turkish Society of Algology

(c) (7) क्? 
day. After the initiation of the treatment, the patient had a sensation of pain in the form of a short-lasting electric shock extending from the back of the left ear to the ophthalmic region which occurred 15-20 times per minute and was not accompanied by autonomic findings. The trigger point was detected on examination and the ESR was $12 \mathrm{~mm} / \mathrm{h}$. The patient had an MR-incompatible implant and thus no cranial magnetic resonance imaging (MRI) scan could be performed. A computed tomography (CT) scan showed normal cerebral and carotid-vertebral arteries on angiography and no intracranial aneurysm or arterial compression that could trigger TN. The vertebral and basilar arteries were also normal. Follow-

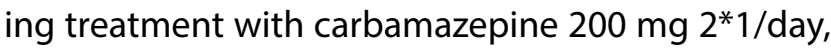
neuralgia completely disappeared. The patient was diagnosed as having TN based on the International Headache Society (IHS) diagnostic criteria.

\section{Discussion}

Temporal arteritis (TA) may manifest with central and peripheral nervous system findings. TA is an inflammatory granulomatous vasculitis characterized by unilateral headache and vision loss, mostly affecting people aged over 50 years. ${ }^{[1]}$ In a study conducted with 214 patients in 1990, Hunder et al. defined 5 criteria for the diagnosis of TA: (I) an age of $\geq 50$ years at the time of disease onset, (II) localized headache of new onset, (III) sensitivity or decreased pulse of the temporal artery, (IV) ESR $>50 \mathrm{~mm} / \mathrm{h}$, and (V) granulomatous segmental inflammation in temporal artery biopsy. The presence of 3 out of these 5 criteria is diagnostic. ${ }^{[3]} \mathrm{TN}$ is a paroxysmal, suddenonset, severe, short-term, knife-like or electric shocklike pain which is mostly localized in the divisions of the trigeminal nerve and can involve the central or peripheral nervous system. Diagnosis is often made based on patient history. ${ }^{[4]}$ According to the IHS, the diagnostic criteria of TN are as follows: (I) paroxysmal pain attacks that affect one or more branches of the trigeminal nerve and last from one second to two minutes, including criteria II or III, (II) a pain characteristically including at least one of the following criteria: a) intense, sharp, superficial or knife-like pain, b) stimulation of pain with triggering regions or increase with triggering factors, (III) attacks which are different for each patient and patient-specific, and (IV) absence of clinically significant neurological deficit. ${ }^{[5]}$ In a case report published in 2005, Blaise et al. reported that peripheral neuropathy might be a symptom of TA. Of note, the authors also reported that the $\mathrm{C} 5$ root, sciatic, and the medial and radial nerves were involved and ischemia was considered to be the underlying mechanism due to the sudden onset of a C5 plexopathy in the patient. ${ }^{[1]}$ Our patient was a 60-year-old woman and presented with sensitivity in the temporal region, new onset of gradually increasing headache, and blurry vision. Moreover, laboratory workup indicated an ESR of over $100 \mathrm{~mm} / \mathrm{h}$. Following the diagnosis, however, the ESR became normal and the patient was diagnosed as having TN due to the presence of electric shocklike recurrent pain which lasted for 5-10 seconds in the same area throughout the day. In a previous case report, Jundt et al. evaluated a patient with TA and reported that occipital artery inflammation was present in the aetiology of occipital neuralgia while sedimentation was normal. ${ }^{[6]}$ Similarly, literature reviews indicate that the coexistence of TA and TN may have an etiology of ischemia or inflammation. $[1,6]$ Kawaguchi et al. reported that the coexistence of TN and TA is extremely rare..$^{[2]}$ In our patient, the treatment was performed without biopsy due to the risk of vision loss and urgent treatment indications and also because TA biopsy is not performed in our centre. A computed tomography (CT) scan and carotid-vertebral arteries on angiography showed normal. Accordingly, Ischemia was ruled out in the etiology of TN secondary to TA. Additionally, due to the presence of ophthalmic branch involvement and the anatomical proximity of the ophthalmic branch of the trigeminal nerve to the temporal artery, we considered that the aetiology was not coincidental.

In conclusion, the case presented in this report indicated that inflammation may play a role in the pathogenesis of TN secondary to TA. Moreover, given that inflammation may be present despite normal ESR levels, as seen in our patient, inflammation can be considered in the etiology of this condition once other causes have been ruled out.
Informed Consent: Written informed consent was obtained from the patient who participated in this study.

Conflict-of-interest issues regarding the authorship or article: None declared.

Peer-rewiew: Externally peer-reviewed. 


\section{References}

1. Blaise S, Liozon E, Nadalon S, Vidal E. Horton's disease revealed by brachial C5 plexopathy. Rev Med Interne 2005;26(7):578-82. [CrossRef]

2. Kawaguchi Y, Ebina M, Sato T, Ishiguro Y, Yagihashi S, Hirota $\mathrm{K}$. A case of trigeminal neuralgia complicated by ipsilateral temporal arteritis. J Anesth 2010;24(1):139-42. [CrossRef]

3. Hunder GG, Bloch DA, Michel BA, Stevens MB, Arend WP, Calabrese $\mathrm{LH}$, et al. The American College of Rheumatol- ogy 1990 criteria for the classification of giant cell arteritis. Arthritis Rheum 1990;33(8):1122-8. [CrossRef]

4. Cruccu G. Trigeminal Neuralgia. Continuum (Minneap Minn) 2017;23(2):396-420. [CrossRef]

5. Headache Clasification Subcommittee of the International Headache Society. The International Clasification of Headache Disorders. Cefalgia 2004;24(1):126-7.

6. Jundt JW, Mock D. Temporal arteritis with normal erythrocyte sedimentation rates presenting as occipital neuralgia. Arthritis Rheum 1991;34(2):217-9. [CrossRef] 